\title{
(2) \\ Commercialization of Underutilized Plants in Uganda: An analysis of the market chains of Luffa cylindrica (L.) M.Roem.
}

\author{
Akankwasah Barirega and Patrick Van Damme
}

\section{Research}

\begin{abstract}
Luffa cylindrica (L.) M.Roem. (Cucurbitaceae) is an important plant with numerous domestic and industrial applications. In Uganda, mature fruits of this plant are sold in many markets as bathing sponges. The species has recently been identified as a priority plant for commercialization in Uganda. However, little is known about the structure and functioning of its value chain, demand and supply dynamics, and economic viability of its trade. The objectives of this study were therefore to document and characterize luffa's value chain, assess its demand and supply, and to evaluate economic viability of the plant's trade in Uganda. Primary and secondary data were collected through market surveys and focus group discussions covering the seven major markets in Kampala City, Uganda. A total of 112 value chain actors were interviewed and two focus group discussions conducted with luffa traders. This study mapped and characterized the value chain of luffa in Uganda. The plant value chain was found to be fairly elaborate with farmers, primary processors, transporters, secondary processors, wholesalers, retailers, and consumers recorded as major actors. Lack of market information, competition from alternative products, and lack of awareness about alternative uses of luffa products were found to be the major bottlenecks in the luffa value chain. Despite luffa's several domestic and industrial potential alternative uses, the study reveals that in Uganda, luffa is dominantly utilized as a bathing sponge. The supply of luffa to the market was found to be high as compared to the available demand. The luffa sponge traders were found to be economically benefiting from the trade with up to $30 \%$ net profit margins recorded in this study. While luffa is still underutilized relevant to its potential value, commercialization of the plant is slowly emerging in Uganda.
\end{abstract}

\section{Introduction}

Luffa cylindrica (L.) M.Roem., commonly referred to as luffa, loofa, sponge gourd, vegetable sponge, bath sponge, or dish cloth gourd, is a cross-pollinated plant species belonging to the Cucurbitaceae (Bal et al. 2004). The plant is believed to be indigenous to America (Mazali \& Alves 2005) but has a long history of cultivation in the tropical countries of Asia and Africa (Sangh et al. 2012).

The plant produces fibrous-spongy fruit composed of $60 \%$ cellulose, $30 \%$ hemicelluloses, and 10\% lignin (Mazali \& Alves 2005). Luffa fruit have numerous applications including food, medicine, sponges, crafts, and packaging, as well as shock and sound absorption (Oboh \& Aluyor 2009). Mature fibers of luffa are useful for washing ships and decks and for manufacturing slippers, baskets, pillows, shoe mats and soles, factory filters, and bonnet lining (Bal et al. 2004, Oboh \& Aluyor 2009).

\section{Correspondence}

Akankwasah Barirega, Makerere University College of Agricultural and Environmental Sciences, P.O. Box 7062, Kampala, UGANDA. bakankwasah@caes.mak.ac.ug,

Patrick Van Damme, Faculty of Bio-Science Engineering, Department of Plant Production, Coupure links 653, 9000 Ghent, BELGIUM, and Faculty of Tropical AgriSciences, Czech University of Life Sciences Prague, Kamycka 129, Prague 6 - Suchdol, 165 21, CZECH REPUBLIC. patrick.vandamme@UGent.be

Ethnobotany Research \& Applications 12:525-533 (2014)

Published: 24 November 2014 
Seeds of L. cylindrica contain about $40 \%$ oil used in the manufacture of fertilizers and animal feeds (Lee \& Yoo 2006) and production of biodiesels (Ajiwe et al. 2005). Immature fibers of the plant contain vegetable proteins useful for animal and human health (Oboh \& Aluyor 2009). Immature fibers can be eaten raw like cucumbers or cooked like squash, while young leaves, shoots, and flower buds as well as the flowers can be eaten after being lightly steamed, and the seeds may be roasted and eaten as a snack (Sangh et al. 2012).

Luffa has several medicinal applications in South America, Asia, and tropical Africa. The plant is used in treatment of fever, enteritis and swelling (Lee \& Yoo 2006), syphilis, tumors, bronchitis, splenopathy, leprosy, asthma, skin diseases, splenic enlargement, rheumatism, nephritis, shingles, boils, backache, internal hemorrhage, putrid fevers, jaundice, and chest pains as well as hemorrhoids (Sangh et al. 2012). Luffa fruit have also exhibited anthelmentic, carminative, laxative, depurative, emollient, expectorant, tonic, and galactagogue properties (Sangh et al. 2012). They are also carriers of microorganisms, and plant and animal cells (Chen et al. 2003).

Luffa is globally recognized as a plant of high economic importance with commercial production reported in China, Korea, India, Nepal, Japan, and Central America (Bal et al. 2004, Mazali \& Alves 2005, Oboh \& Aluyor 2009). In Uganda, this plant has been identified as one of the underutilized plants which once commercialized could generate economic benefits to the people (Barirega et al. 2012).

Despite the plant's numerous existing and potential applications reported in gray and formal scientific literature, analysis of its value chain has not been given much attention in Uganda (Barirega et al. 2012). Literature on the value chain of this plant in Uganda is anecdotal or nonexistent. Little is known about the demand and supply potential of the plant and its economic importance in Uganda (Barirega et al. 2012, Jensen 2009). Consequently, it is still regarded as a low economic priority plant in Uganda.

This study sought to bridge the knowledge gap by analyzing the market chain of luffa in Uganda. The objectives of the study are: (1) document and characterize value chains of $L$. cylindrica in Uganda, (2) assess its market demand and supply, and (3) evaluate economic viability of luffa trade in Uganda.

\section{Materials and Methods}

\section{Study area}

The study was conducted in all six major markets of Kampala city, the Ugandan capital. These were Owino and Nakasero in Central division, Nakawa in Nakawa division, Nateete and Ndeeba in Rubaga division, and Kalerwe in
Kawempe division. Kampala city markets were chosen because they receive products from all over the country and are therefore the best representatives of Ugandan markets.

Kampala city is situated in central Uganda and is Uganda's commercial center. The city has a resident population of 1.6 million people and a daily transient population of about 2.3 million (Uganda Bureau of Statistics 2005). The annual city population growth rate of Kampala as of 2005 was $3.9 \%$ and average density was 51 inhabitants/ha.

The major economic activity in the city is trade. According to Africa Development Bank (2009), Kampala markets are generally described as non-specialized, poorly managed, overwhelmed by vendors beyond their carrying capacities, and lacking in many basic amenities required of a well-functioning market.

\section{Data collection}

Field work for this study was conducted between July 2011 and May 2012 with the help of two research assistants. The research assistants were from Kampala, were knowledgeable of the study area, and spoke the local languages of the city. This was useful in rapport- and confidence-building during the survey (Tabuti 2003).

Prior to interviewing respondents, this study was introduced to the market chairperson, and this introduction was repeated whenever a new market was entered. The same introduction was made to respondents, and consent was sought from each respondent before interviewing him or her.

A reconnaissance market survey lasting for two weeks was carried out in Owino, Kalerwe, and Nateete markets in June 2011. This was aimed at better understanding the study area, and responses from this study were used in revising the research tool to suit the study area.

To identify the luffa vendors at the markets, a snowball sampling method as described in Giuliani and Padulosi (2005) and De Caluwe (2011) was used. A total of 112 luffa traders were interviewed in this study in all seven markets studied.

A survey questionnaire consisting of open and closed questions was administered in face-to-face interviews conducted in Luganda (local language) or English, according to participants' preferences. Each respondent was asked about the source of luffa supply, costs involved in selling and buying, and perceived demand, supply, and household economic importance rating on a scale of 1-5 where 1, 2, 3, 4, and 5 represented very low, low, moderate, high, and very high, respectively. Respondents were also asked about challenges and opportunities in the luffa value chain. 


\section{Barirega - Commercialization of underutilized plants in Uganda: An analysis of the market chains of Luffa cylindrica (L.) M.Roem.}

We also conducted one focus group discussion with the luffa trader's association executive members to triangulate the trader's survey and understand the entire value chain of luffa.

\section{Data analysis}

Data collected was coded and imported into Statistical Package for Social Sciences (SPSS 17) for descriptive and inferential analysis. Responses from open-ended questions were grouped into classes that expressed similar ideas while percentages based on valid responses only were calculated from closed-ended questions.

Socio-economic characteristics were summarized into frequency and percentage tables. Perceived demand, supply, and economic importance ratings on a scale of 1-5 were reduced to aggregate percentages and weekly sales reduced to mean values.

Parametric correlations were calculated using Spearman's rank correlation, and Kendall's tau_b was used for non-parametric correlations at $95 \%$ and $\overline{9} 9 \%$ levels of confidence. Profit margins were derived from the expression $P M=S P-(P P+O C)$, where $P M$ is the profit margin, $\mathrm{SP}$ is selling price, $\mathrm{PP}$ is the purchase price, and $\mathrm{OC}$ is the operational cost of transport and labor (De Caluwe 2011).

The value chain was mapped by identifying actors and then using a box-and-arrow diagram to show their linkages in line with De Caluwe (2011), te Velde et al. (2006), and Vermeulen et al. (2008). The thicker an arrow is, the more important the market chain is to the stakeholders.

\section{Results}

\section{Socio-economic characteristics of luffa vendors}

The study reveals that there is almost equal participation of both sexes in the luffa value chain with women being represented slightly more at $57 \%(n=112)$ than men. The majority of the vendors $(57 \%)$ were married, and $61 \%$ of them were family heads. Most value chain actors $(36 \%)$ were between 21-30 years old, and the highest level of education for the majority of them $(57 \%)$ was Uganda Certificate of Education (UCE) or ordinary level secondary education (Table 1 ). On average, respondents had spent 6 years (range 1-25 years) in the luffa trade.

\section{Luffa uses in Uganda}

The main use of luffa recorded in the survey was the use of dry luffa fruit as a bathing sponge (98\%). Luffa sponge was sold in all the markets studied and along streets. Few vendors $(2 \%)$ reported that immature luffa fruits were used for food as vegetables among non-indigenous communities especially those of Indian origin. Focus group
Table 1. Age, education, and gender of luffa value vendors in Uganda.

\begin{tabular}{|l|l|}
\hline Variable & $\%(\mathbf{n}=\mathbf{1 1 2})$ \\
\hline Age & 3.6 \\
\hline Below 20 years & 35.7 \\
\hline 21-30 years & 25.0 \\
\hline $31-40$ years & 25.0 \\
\hline $41-50$ years & 10.7 \\
\hline Above 50 years & \multicolumn{2}{|l|}{} \\
\hline Gender & 43 \\
\hline Male & 57 \\
\hline Female & \multicolumn{2}{|l|}{} \\
\hline Education & 3.6 \\
\hline No formal education & 17.9 \\
\hline Primary & 57.1 \\
\hline Ordinary level & 7.1 \\
\hline Advanced level & 10.7 \\
\hline Vocational education & 3.6 \\
\hline Diploma & \\
\hline
\end{tabular}

discussions with luffa vendors further revealed that luffa leaves are also used for treatment of stomach ache and inducement of parturition in goats.

\section{Luffa value chain in Uganda}

The study established the chain actors in the luffa value chain to be farmers, wholesalers, retailers in organized markets, mobile vendors, transporters, processors, and consumers (Figure 1). According to the vendors, the farmers pick luffa fruits from small-scale farms where luffa grows with little management.

The retailers are comprised of market vendors in fixed market stalls and mobile vendors operating along busy roads. The wholesalers buy processed luffa sponge from processors and distribute it to retailers in shops and supermarkets and to mobile vendors. The main form of transport was by passenger buses from upcountry, while vendors mainly walk and sometimes use bicycles to sell the sponges.

The processors were mainly of two categories, the first category comprised of individuals based in localities near the farmers. These processors buy mature luffa fruits at lower prices, after which they wash and dry them, making them ready for use. The second category are processers, mainly in urban areas, who resize, pack, and brand the sponge for marketing and selling to mainly corporate consumers through supermarkets and shopping centers. 


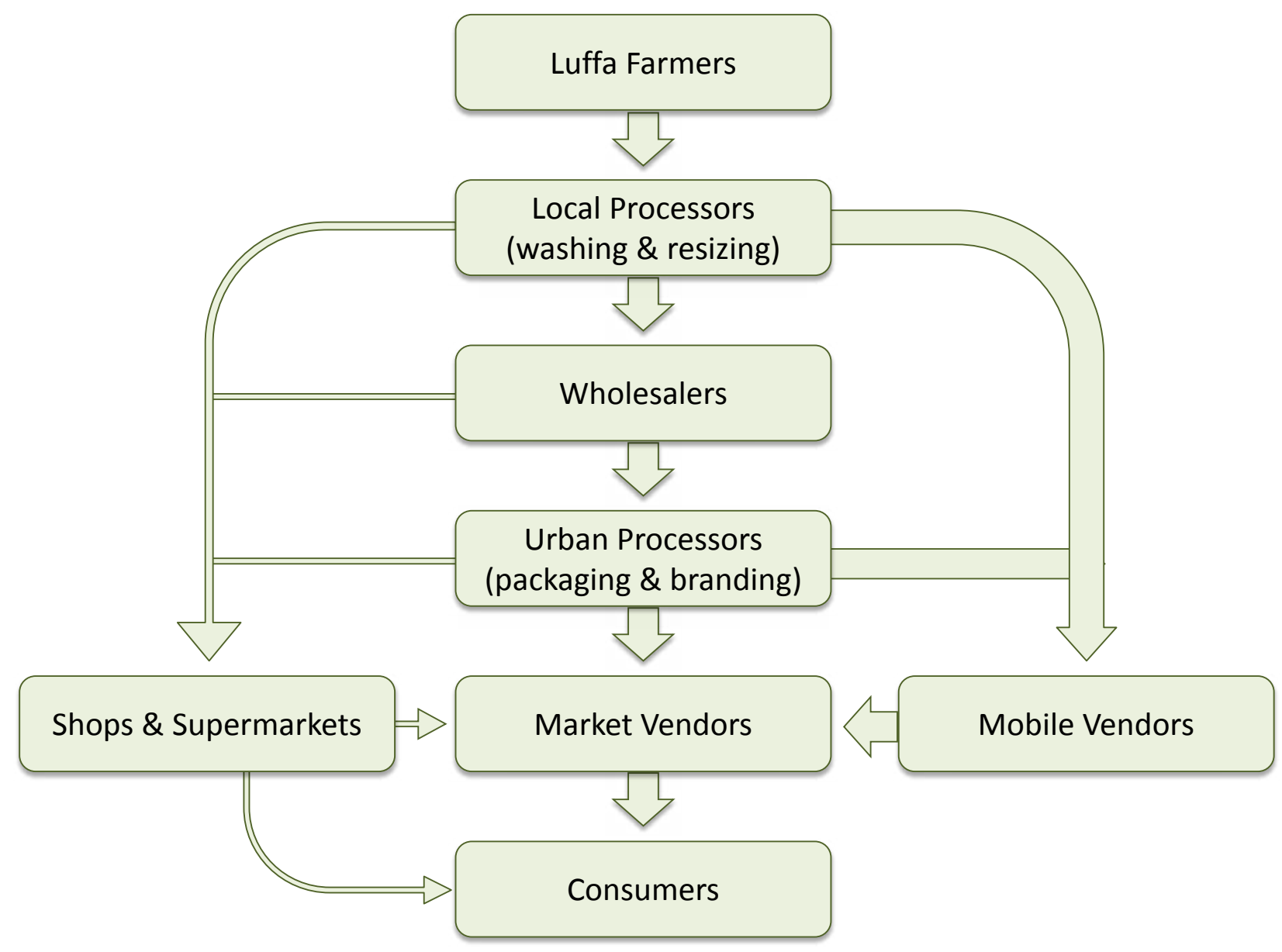

Figure 1. Luffa sponge value chain for Uganda. Thicker lines indicate greater importance within the product flow.

Table 2. Frequency ranking of the sources of luffa in Uganda.

\begin{tabular}{|l|c|}
\hline District & \% ( $\mathbf{n}$ 112) \\
\hline Mpigi & 21 \\
\hline Mayuge & 17 \\
\hline Iganga & 12 \\
\hline Kamuli & 12 \\
\hline Hoima & 7 \\
\hline Jinja & 6 \\
\hline Namutumba & 5 \\
\hline Busembatya & 4 \\
\hline Buyikwe & 4 \\
\hline Luwero & 4 \\
\hline Palisa & 4 \\
\hline Wakiso & 4 \\
\hline
\end{tabular}

The luffa fruits are brought to the city from different upcountry districts, with a relatively wider abundance in the eastern part of Uganda. Many respondents $(21 \%, 24$ vendors) reported that much of the luffa came from Mpigi district, followed by Mayuge (17\%), Iganga (12\%), and Kamuli (12\%) (Table 2). The study did not find luffa seed at markets as farmers retained their own seeds during primary processing.

The respondents identified seasonality of supplies (owing to the sensitivity of the plant to dry seasons), lack of market information particularly on prices, competition from alternative bathing sponges, and lack of extension services particularly on production and processing as some of the major challenges affecting their enterprises (Table 3).

\section{Demand and supply of luffa sponge in Uganda}

The study reveals that the demand of luffa sponge in Uganda is low to moderate. It is a product that is not highly demanded, but still widely used. Of the 112 value 


\section{Barirega - Commercialization of underutilized plants in Uganda: An analysis 529 of the market chains of Luffa cylindrica (L.) M.Roem.}

Table 3. Frequency ranking of the challenges affecting luffa value chain actors in Uganda.

\begin{tabular}{|l|c|}
\hline Challenge & $\begin{array}{c}\text { Percentage } \\
\text { (n = 112) }\end{array}$ \\
\hline $\begin{array}{l}\text { Lack of market information especially } \\
\text { prices and demand }\end{array}$ & 72 \\
\hline $\begin{array}{l}\text { Lack of extension services on farming } \\
\text { and production methods }\end{array}$ & 68 \\
\hline $\begin{array}{l}\text { Unpredictable rainfall patterns (luffa } \\
\text { is susceptible to dry season) }\end{array}$ & 60 \\
\hline $\begin{array}{l}\text { Competition from other types of } \\
\text { sponges on the market }\end{array}$ & 54 \\
\hline Diseases (wilt) & 18 \\
\hline Seasonality of demand & 12 \\
\hline
\end{tabular}

chain actors interviewed, $36 \%$ rated the demand for luffa sponge to be low, while $29 \%$ rated demand as moderate (Figure 2). It was reported that the demand is seasonal, the peak coinciding with the beginning of the school season.
On average, a trader sold 35 luffa sponges in a week. The best performing trader sold up to 500 sponges. The number of customers received in a week was slightly correlated with the number of years a trader had spent in luffa trade (Pearson rho $=0.293, p=0.002, n=112$ ). Perceived demand also fairly increased with the number of years a trader had spent in trade (Pearson rho $=0.312, p=0.002$, $\mathrm{n}=112$ ).

Most of the value chain stakeholders (57\%, 64 vendors) rated the supply of the sponge as very high, followed by $21 \%$ rating it as high (Figure 2 ). Supply was significantly positively correlated with demand, but the relation between these two variables is weak (Pearson rho $=0.174$; $p=0.03 ; n=112$ ).

\section{Economic potential of luffa sponge}

The price in Ugandan shillings (UGX) at which an average-sized luffa sponge was being bought from the farmer was UGX 300-1000 (USD 0.12-0.40), depending on quality. The selling price after primary processing was UGX 1000-1500 (USD 0.40-0.60), while the price after

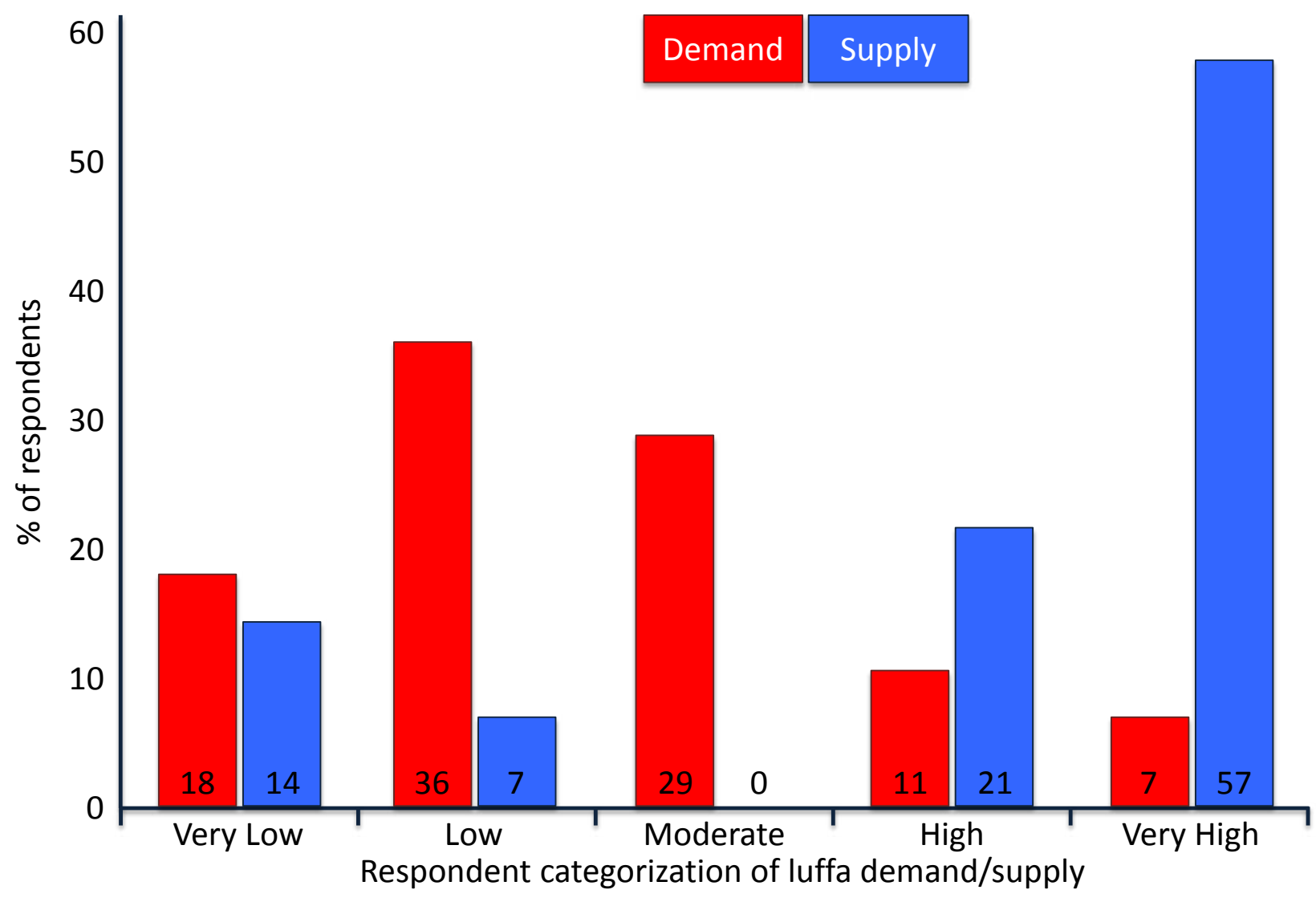

Figure 2. Interview respondents' opinions about luffa sponge supply/demand in Uganda. 
secondary processing and packaging was UGX 20002500 (USD 0.80-1.00) (Table 4).

Table 4. Economic potential of luffa sponge in Uganda. Average exchange rate for study period: USD1 = UGX2500.

\begin{tabular}{|l|l|l|}
\hline $\begin{array}{l}\text { Luffa product } \\
\text { (Bathing sponge) }\end{array}$ & $\begin{array}{l}\text { Consumer } \\
\text { price } \\
\text { (USD/piece) }\end{array}$ & $\begin{array}{l}\text { Gross } \\
\text { profit } \\
\text { margin \% }\end{array}$ \\
\hline Raw from the garden & $0.12-0.4$ & N/A \\
\hline $\begin{array}{l}\text { Primary processed } \\
\text { (washed and resized) }\end{array}$ & $0.4-0.6$ & 233 \\
\hline $\begin{array}{l}\text { Secondary processed } \\
\text { (packaged and branded) }\end{array}$ & $0.8-1.0$ & 100 \\
\hline
\end{tabular}

During the study period, average weekly net profits for luffa value chain players was found to be USD 6.40, whereas total average weekly income of traders was estimated to be USD 21.20 , translating into a $30.2 \%$ contribution to the luffa trader's cash income. The economic importance rating of luffa was significantly positively correlated to demand ratings (Pearson rho $=0.594, p=0.003, n=112$ ).

\section{Discussion}

\section{Luffa sponge value chains in Uganda}

The value chain map of luffa reveals that the chain is long with six nodes. According to Shahidullah and Haque (2010), a value chain with more than three key actors is considered long and inefficient. They argue that an efficient value chain comprised of producers, processors, and consumers has more benefits and is more transparent because market information moves readily among nodes. Long chains are associated with low prices to primary producers because middlemen tend to exploit them by distorting market information (Riddihough \& Jones 1996).

Equal participation of female and male vendors represents an opportunity for value chain improvement. Ward et al. (2010) reports that gender balance in agricultural productivity brings about equal distribution of resources resulting in production efficiency and increased incomes. Gender complementarity is necessary for commercialization of underutilized plants since each of the actors have a unique role to play (De Caluwe 2011, Delacote 2007, Marshall et al. 2006).

Most of the vendors are literate, which according to Gizachew (2006) promotes efficient flow of market information in value chains. The luffa chain therefore presents an opportunity for provision of market information which is necessary for efficient functioning of a value chain.
The number of years spent in luffa trade that was reported by the chain actors is indicative of a chain with actors of a reasonable experience. Experience was found to slightly influence sales. This means that the actors are likely to sell more luffa in a given time, the longer they stay in the luffa trade. In Ethiopia, experience of chain actors was also found to positively influence volumes in trade and production in general (Weldeslassie 2007).

The problems identified in the value chain are characteristic of many value chains of underutilized plants in developing countries. Inefficient value chains and associated problems have been recorded for underutilized plants elsewhere (see Agea et al. 2011, De Caluwe 2011). Absence of a seed supply system in the value chain is a typical feature in less-developed value chains for underutilized plants (Jaenicke et al. 2006). In order to improve the value chain of luffa, solutions to the problems identified should be devised. This study attempts to contribute to this process.

\section{Demand and supply of luffa sponge in Uganda}

Despite the vendors' perception that the supply of luffa sponge is high, the demand recorded by the present study is predominantly low. Cunningham (2001) argues that if demand for a species or product is high and supplies are still available, then the species will be sold in many market places. In this instance, the species is common in markets, and the supply is high but demand low.

According to De Caluwe (2011), demand for underutilized plants is determined by the quantities that people are willing and financially able to purchase. The observed low demand could therefore be due to the low purchasing power of the luffa users. Presence of alternative bathing sponges observed at the markets could also be responsible for the low demand of luffa.

The weak positive correlation of demand with the number of years spent in luffa trade is probably due to positive impact of trade experience that grows over time. As one stays in trade, he/she develops a customer base. This explains why some value chain actors in this study rated luffa demand high, while others rated it low. This means that demand accrues from individual effort and not for luffa as a product. A similar situation is reported by Weldeslassie (2007) in Ethiopian markets for underutilized plants.

The present study indicates that luffa supply is slightly positively correlated with demand for luffa. Farmers of luffa produce not just to meet market requirement but rather to maximize their supply. When the market is expanded, the farmers can still meet the demand since the supply is still way above the demand. The current market of luffa is domestic because the chain did not have an export segment. Given low demand recorded, efforts to widen the 


\section{Barirega - Commercialization of underutilized plants in Uganda: An analysis 531 of the market chains of Luffa cylindrica (L.) M.Roem.}

market of luffa would be beneficial to farmers and other value chain actors.

While luffa has numerous uses (Bal et al. 2004, Oboh \& Aluyor 2009), this study documents predominant use of luffa as a bathing sponge, hence limited demand. Full potential of the plant is not yet realized. This could be due to limited awareness about other uses of luffa and associated values. According to Lawrence (2003), awareness about a plant and its uses raises its demand.

\section{Economic viability of luffa sponge trade}

Economic importance and value of natural resources in general to the lives of people has been documented by numerous scholars (Campbell \& Luckert 2002, Dubois 2003, Oboh \& Aluyor 2009). The present study confirms the fact that underutilized plants at the national level have the potential to contribute to household cash incomes at the local level in urban and rural areas.

To our knowledge, the present study is the first to obtain an insight into the structure and functioning of luffa value chains in Uganda. While the study could not establish net profit values on a unit cost due to lack of reliable information on unit transaction costs, the average contribution to traders' cash incomes of $30.2 \%$ calculated from weekly reported figures is within the reported ranges of $20-50 \%$ reported by Ambrose-Oji (2003) and Narendran et al. (2001) for underutilized plants in general.

The present findings are also consistent with Fandohan et al. (2010) who reported $8.8-56.4 \%$ cash income contribution to tamarind fruit traders in Benin. Based on the findings of this study, it is concluded that Luffa cylindrica is a plant that falls in the gap-filling income category of underutilized plants as also described by Marshall et al. (2006).

The plant is therefore of economic potential to the rural as well as urban economies of Uganda. Organizing luffa farmers into a well-coordinated group and marketing of luffa products nationally and internationally could result in the plant playing a much bigger role in livelihood enhancement in Uganda.

\section{Conclusions and Recommendations}

Luffa cylindrica (L.) M.Roem. is a plant that has potential to contribute to economic development of Uganda. However, the potential of this plant is not fully utilized in Uganda. The plant value chain is fairly long with farmers, primary processors, transporters, secondary processors, wholesalers, retailers, and consumers being the major actors. The value chain lacks good flow of market information, organization, and awareness about alternative uses of luffa products, and suffers from competition from alternative products. The plant is predominantly utilized as a bathing sponge, which is currently the only product in the value chain in Uganda. The value chain has adequate supply in excess of the current demand. Despite the challenges, luffa sponge trade is found to be viable with $30 \%$ cash contribution to the trader's cash income and gross margins of $100-223 \%$.

As a result, this study recommended that:

i. Luffa farmers be organized in groups so that they can jointly promote the trade of the plant;

ii. Government of Uganda, especially the Ministry of Agriculture, should promote investment in secondary processing of luffa sponge into high quality sponges that can compete favorably with other fabric sponges on the market;

iii. Farmers should be supported through provision of affordable credit and skills enhancement to promote medicinal and industrial uses of luffa in Uganda; and

iv. In-depth value chain analysis of individual segments of the luffa value chain should be undertaken to further understand the determinants of demand and supply of luffa in Uganda.

\section{Acknowledgments}

I wish to acknowledge the two research assistants, Ms. Nakiberu Hajara and Mr. Mulindwa Daniel, who were very instrumental in collection of data for this study. Great appreciation goes to Prof. John R.S. Tabuti for guidance throughout the study period. Sincere gratitude also goes to the German Academic Exchange Service (DAAD) for funding this study.

\section{Literature Cited}

Africa Development Bank. 2009. Markets and Agricultural Trade Improvement Project - I (MATIP-I). Country: Uganda. Project Appraisal Report. www.afdb.org Accessed 02 August 2014.

Agea, J.G., J.M. Kimondo, C.A. Okia, R.A.A. Abohassan, J. Obua, J. Hall \& Z. Teklehaimanot. 2011. Contribution of wild and semi-wild food plants to overall household diet in Bunyoro-Kitara Kingdom, Uganda. Agricultural Journal 6(4):134-144. dx.doi.org/10.3923/aj.2011.134.144

Ajiwe, V.I.E, G.I. Ndukwe, \& I.E. Anyadiegwu. 2005. Vegetable diesel fuels from Luffa cylindrica oil, its methylester and ester-diesel blends. Chemclass Journal 2:1-4.

Ambrose-Oji, B. 2003. The contribution of NFTPs to the livelihoods of the forest poor: Evidence from the tropical forest zone of south-west Cameroon. International Forestry Review 5(2):106-117. dx.doi.org/10.1505/ IFOR.5.2.106.17420 
Bal, K.E, Y. Bal \& A. Lallam. 2004. Gross morphology and absorption capacity of cell-fibers from the fibrous vascular system of loofah (Luffa cylindrica). Textile Research Journal 74(3):241-247. dx.doi. org/10.1177/004051750407400310

Barirega, A., J.G.Agea \& P. Van Damme. 2012. Prioritizing wild medicinal and food plants with potential for commercialization and value chain improvement for livelihood enhancement and poverty reduction in Uganda. Research Journal of Environmental and Earth Sciences 4(6):668673. http://hdl.handle.net/1854/LU-3150835

Campbell, B.M. \& M.K. Luckert. 2002. Towards understanding the role of forests in rural livelihoods. Pp. 1-16 in Uncovering the Hidden Harvest: Valuation methods for woodland and forest resources. Edited by B.M. Campbell \& M.K. Luckert. Center for International Forestry Research (CIFOR), Bogor, Indonesia.

Chen, J.-P., S.-C. Yu, B.R.-S. Hsu, S.-H. Fu \& H.-S. Liu. 2003. Loofa sponge as a scaffold for the culture of human hepatocyte cell line. Biotechnology Progress 19(2):522527. dx.doi.org/10.1021/bp025720j

Cunningham, A.B. 2001. Applied Ethnobotany: People, wild plant use and conservation. People and Plants Conservation Manuals, Earthscan Publications, London, U.K.

De Caluwe, E. 2011. Market Chain Analysis of Baobab (Adansonia digitata L.) and Tamarind (Tamarindus indica L.) Products in Mali and Benin. Ph.D. thesis, Faculty of Bioscience Engineering, Ghent University, Ghent, Belgium.

Delacote, P. 2007. Agricultural expansion, forest products as safety nets, and deforestation. Environment and Development Economics 12(2):235-249. dx.doi.org/10.1017/ $\underline{\mathrm{S} 1355770 \times 06003482}$

Dubois, O. 2003. Forest-based poverty reduction: A brief review of facts, figures, challenges and possible ways forward. Pp. 65-86 in Forests in Poverty Reduction Strategies: Capturing the potential. EFI Proceedings No. 47. Edited by T. Oksanen, B. Pajari \& T. Tuomasjukka. European Forest Institute (EFI), Torikatu, Joensuu, Finland.

Fandohan, B., A.E. Assogbadjo, R. Glélé Kakai, T. Kyndt, E. De Caluwé, J.T.C. Codjia \& B. Sinsin. 2010. Women's traditional knowledge, use value, and the contribution of tamarind (Tamarindus indica L.) to rural households' cash income in Benin. Economic Botany 64(3):248-259. dx.doi.org/10.1007/s12231-010-9123-2

Giuliani, A. \& S. Padulosi. 2005. Enhancing the value chain for markets for traditional products of neglected and underutilized aromatic, vegetable and fruit species in the
Near East: A pilot study in Syria. Pp. 428-439 in Proceedings of the International Conference on Promoting Community-driven Conservation and Sustainable Use of Dryland Agrobiodiversity. 18-21 April 2005, Aleppo, Syria. Edited by A. Amri \& A. Damania. International Center for Agricultural Research in the Dry Areas, Beirut, Lebanon.

Gizachew, G. 2006. Dairy Marketing Patterns and Efficiency: A case study of Ada'a liben district of Oromia region, Ethiopia. MSc thesis, Alemaya University (now Haramaya University), Dire Dawa, Ethiopia.

Jaenicke, H., I. Hoschle-Zeledon \& N. Manning, eds. 2006. Proceedings of Regional Consultation Workshop: Strategies for research and development of underutilised plant species in Africa. 24-26 May 2006, Nairobi, Kenya. International Centre for Underutilised Crops (ICUC), Colombo, Sri Lanka, and Global Facilitation Unit for Underutilized Species (GFU), Rome, Italy.

Jensen, A. 2009. Valuation of non-timber forest products value chains. Forest Policy and Economics 11(1):34-41. dx.doi.org/10.1016/j.forpol.2008.08.002

Lawrence, A. 2003. No forest without timber? International Forestry Review 5(2):87-96. dx.doi.org/10.1505/ IFOR.5.2.87.17411

Lee, S. \& J.G. Yoo. 2006. (WO/2006/019205) Method for preparing transformed Luffa cylindrica Roem. World Intellectual Property Organization. http://patentscope.wipo.int/ search/en/WO2006019205. Accessed 16 January 2013.

Marshall, E., K. Schreckenberg \& A.C. Newton, eds. 2006. Commercialization of Non-Timber Forest Products: Factors influencing success. Lessons learned from Mexico and Bolivia and policy implications for decision-makers. United Nations Environment Programme World Conservation Monitoring Centre, Cambridge, U.K.

Mazali, I.O. \& O.L. Alves. 2005. Morphosynthesis: High fidelity inorganic replica of the fibrous network of loofa sponge (Luffa cylindrica). Annaes da Academia Brasileira de Sciências 77(1):25-31. dx.doi.org/10.1590/S0001$\underline{37652005000100003}$

Narendran, K., I.K. Murthy, H.S. Suresh, H.S. Dattaraja, N.H. Ravindranath \& R. Sukumar. 2001. Nontimber forest product extraction, utilization and valuation: A case study from the Nilgiri Biosphere reserve, southern India. Economic Botany 55(4):528-538. dx.doi.org/10.1007/ BF02871715

Oboh, I.O. \& E.O. Aluyor. 2009. Luffa cylindrica - An emerging cash crop. African Journal of Agricultural Research 4(8):684-688. 


\section{Barirega - Commercialization of underutilized plants in Uganda: An analysis 533 of the market chains of Luffa cylindrica (L.) M.Roem.}

Riddihough, P. \& N. Jones. 1996. Some Marketing Problems Faced by Agro-forestry Farmers in Asia. FAO Documents Repository, Non wood Forest Products-3. Food and Agriculture Organization of the United Nations (FAO), Rome, Italy.

Sangh, P., A. Kumar, N.K. Sharma \& K.K. Jha. 2012. Luffa cylindrica: An important medicinal plant. Journal of Natural Products and Plant Resources 2(1):127-134.

Shahidullah, A.K.M. \& C.E. Haque. 2010. Linking medicinal plant production with livelihood enhancement in Bangladesh: Implications of a vertically integrated value chain. Journal of Transdisciplinary Environmental Studies 9(2):1-18.

Tabuti, J.R.S. 2003. Locally Used Plants in Bulamogi County, Uganda: Diversity and modes of utilization. Ph.D. Thesis, Agricultural University of Norway, Ås, Norway.

te Velde D.W., J. Rushton, K. Schreckenberg, E. Marshall, F. Edouard, A. Newton \& E. Arancibia. 2006. Entrepreneurship in value chains of non-timber forest products. Forest Policy and Economics 8(7):725-741. dx.doi. org/10.1016/j.forpol.2005.06.010
Uganda Bureau of Statistics (UBOS). 2005. Uganda Population and Housing Census, 2002: Main report. UBOS, Entebbe, Uganda.

Vermeulen, S., J. Woodhill, F. Proctor \& R. Delnoye. 2008. Chain-Wide Learning for Inclusive Agrifood Market Development: A guide to multi-stakeholder processes for linking small-scale producers to modern markets. International Institute for Environment and Development (IIED), London, U.K., and Wageningen University and Research Centre, Wageningen, Netherlands.

Ward, J., B. Lee, S. Baptist \& H. Jackson. 2010. Evidence for Action: Gender equality and economic growth. Programme Report. Chatham House, The Royal Institute of International Affairs, London, U.K. www.chathamhouse. org/publications/papers/view/109478 Accessed 28 April 2013.

Weldeslassie, A.A. 2007. Vegetable Market Chain Analysis in Amhara National Regional State: The case of Fogera Woreda, South Gondar. MSc thesis, Haramaya University, Dire Dawa, Ethiopia. 
